\title{
ANALISIS PENENTUAN JUMLAH TENAGA KERJA DAN KELUHAN RASA SAKIT DENGAN MENGGUNAKAN METODE WORKLOAD ANALYSIS DAN SNQ
}

\author{
Yumi Damai Yanti ${ }^{1}$, Idzani Muttaqin ${ }^{1}$, Ice Trianiza ${ }^{1}$ \\ ${ }^{1}$ Teknik Industri, Fakultas Teknik, Universitas Islam Kalimantan Muhammad Arsyad Al-Banjari \\ J1. Adhyaksa, Jl. Kayu Tangi 1 Jalur 2 No.2, Sungai Miai, Kec. Banjarmasin Utara, Kota Banjarmasin, \\ Kalimantan Selatan 70123 \\ Email : cintiaamaliatpc@gmail.com
}

\begin{abstract}
Abstrak-UD. Budi Ayu merupakan salah satu industri kecil yang bergerak di bidang pengolahan material bahan bangunan berupa paving block dan batako dinding. Penelitian dilakukan karena adanya ketidakseimbangan beban kerja antar stasiun kerja dan keluhan rasa sakit yang dialami oleh para pekerja karena beban kerja yang berlebih. Penelitian bertujuan menganalisis beban kerja tiap-tiap bagian dan menentukan jumlah tenaga kerja optimal serta untuk menganalisis keluhan rasa sakit di bagian tubuh yang dialami oleh para pekerja. Metode Workload Analysis digunakan untuk mengetahui beban kerja dari masing-masing pekerja. Metode work sampling digunakan untuk mendapatkan persentase waktu produktif sedangkan untuk mengetahui keluhan rasa sakit digunakan SNQ (Standard Nordic Questionnaire) yang dibagikan kepada para pekerja. Berdasarkan hasil penelitian yang telah dilakukan maka didapatkan bahwa hamper seluruh pekerja memiliki beban kerja lebih dari $100 \%$ kecuali pekerja 5 yang hanya memiliki beban $\mathbf{9 0 , 4 1 \%}$. Bagian batako dinding merupakan bagian yang memiliki beban kerja paling tinggi yaitu sebesar $123,2 \%$. Beban kerja kerja yang tinggi ini jika dibiarkan secara terus menerus tanpa adanya perbaikan dapat berakibat pada fisik pekerja maupun kualitas hasil kerja. Usulan yang diberikan adalah menambah pekerja 1 orang dibagian batako dinding sehingga dapat mengurangi beban kerja dibagian tersebut dan dengan adanya penambahan pekerja tadi dapat di manfaatkan untuk membantu pekerjaan distasiun lain yang membutuhkan sedangkan Keluhan otot terbesar yang dialami pekerja selama bekerja yaitu pada tubuh bagian pinggang dengan persentase sebesar $12,70 \%$.
\end{abstract}

Kata Kunci: Beban Kerja, Work Sampling, Workload Analysis (WLA)

\section{PENDAHULUAN}

$\mathrm{B}$ erbagai macam industri mengalami perkembangan yang cukup meningkat. Salah satunya bidang industri yang berkembang adalah industri konstruksi khususnya pembangunan infrastruktur dan properti yang membutuhkan material salah satunya adalah paving block.

Paving block merupakan salah satu produk bahan bangunan dari semen dan digunakan sebagai salah satu alternative penutup atau pengerasan tanah. Paving block disebut juga bata beton. Paving blok terbuat dari campuran semen, pasir, batu abu (agregrat halus), dan air dengan atau tanpa tambahan lainnya. Ada berbagai bentuk dan ukuran paving block yang variasinya tergantung dari pabrik pembuatnya.

Efektivitas, efisiensi, dan produktivitas penting dalam suatu perusahaan. Untuk memyikapi hal tersebut, salah satu tindakan yang perlu dilakukan adalah pengoptimalan jumlah tenaga kerja yang digunakan. Tenaga kerja merupakan faktor yang paling penting dalam menjamin kelancaran proses produksi. Ketersediaan tenaga kerja dengan tingkat keterampilan yang memadai dan jumlah yang tepat selalu menjadi tujuan dari pelaksanaan produksi itu sendiri, meskipun tidak melupakan faktor penting lainnya yang berpengaruh dalam proses produksi seperti mesin, peralatan dan lain sebagainya.

Beban kerja adalah banyaknya pekerjaan yang harus dilakukan untuk menyelesaikan suatu pekerjaan. Secara fisiologis dalam ergonomi ada 3 jenis beban kerja, yaitu beban kerja fisik, energetis yaitu beban kerja yang ditimbulkan oleh kerja fisik atau otot, beban kerja fisik energetis dibedakan menjadi beban kerja statis dan beban kerja dinamis. Kedua, beban kerja perseptif yaitu beban kerja yang ditimbulkan oleh beban kerja mental (otak) dan kerja panca indera terutama penglihatan dan pendengaran, keterlibatan kontraksi otot dan dengan sendirinya sumber energi atau kalor yang mendukungnya relative kecil. Ketiga, beban kerja biomekanik yaitu beban kerja yang disebabkan terutama oleh kerja statis dan kerja dinamis yang berhubungan dengan sikap tubuh atau bagian tubuh serta berat badan pada waktu kerja yang kurang tepat [1].

Pada umumnya suatu organisasi bisnis didirikan untuk memperoleh keuntungan atau laba. Untuk keperluan tersebut maka didalam perusahaan harus dibentuk berbagai fungsi, seperti fungsi produksi, keuangan, sumber daya manusia, informasi dan teknologi dan juga pemasaran. Sistem kerja untuk setiap proses bisnis tersebut diatas dapat diukur performa kinerjanya dengan menggunakan beberapa kriteria, yaitu kriteria ongkos, kualitas, kuantitas, maupun waktu [16].

Pengukuran beban fisik diukur dari pendekatan work sampling. Metode work sampling merupaka salah satu metode pendekatan yang bisa digunakan untuk mengukur produktivitas dengan mudah. Work sampling juga dapat digunakan untuk mengetahui aktivitas produktif dan tidak produktif operator.

Metode Work Load Analysis (WLA) dilakukan untuk mengetahui tingkat efisiensi kerja berdasarkan total persentase beban kerja yang diberikan untuk menyelesaikan pekerjaannya [12]. Workload Analysis (WLA) merupakan salah satu cara yang dapat digunakan untuk menghitung besarnya beban kerja yang diakibatkan oleh aktivitasaktivitas yang dilakukan. Metode ini dapat menganalisis beberapa penyebab besarnya beban kerja serta menentukan solusi perbaikan untuk menurunkan beban kerja yang tinggi. Selain itu, beban kerja yang diterima oleh pekerja juga dapat digunakan untuk menentukan jumlah pekerja yang perlu dimiliki oleh perusahaan.

UD. Budi Ayu merupakan industri pengolahan paving block yang berdiri sejak tahun 2006 dengan kapasitas produksi 1. 500 unit dalam sehari. Produk yang dihasilkan adalah paving block dan batako dinding. 
Penelitian berdasarkan beban kerja juga pernah dilakukan oleh Fajar Dwi Kurniawan dan Laila Nafisah pada tahun 2020 dalam penelitian yang berjudul "Analisis Beban Kerja dan Penentuan Jumlah Tenaga Kerja Pada Stasiun Kerja Penulangan Plant 1 Dengan Metode Workload Analysis Pada PT. Wijaya Karya Beton". Pada penelitian tersebut berdasarkan hasil penelitian ini dapat diambil kesimpulan bahwa tingkat beban kerja pekerja PT. Wijaya Karya Beton pada stasiun penulangan jalur 1 memiliki nilai beban kerja yang kurang optimal. Oleh karena itu dilakukan perbaikan dengan mengurangi pekerja sebanyak 3 orang yang bisa dialihkan pada stasiun kerja lainnya sehingga menjadi menjadi 3 orang.

\section{METODE PENELITIAN}

\section{Identifikasi Masalah}

Identikasi masalah dalam penelitian ini yaitu mengenai beban kerja dan jumlah tenaga kerja serta tingkat keluhan rasa sakit tenaga kerja pada bagian produksi di UD. Budi Ayu

\section{Instrumen Penelitian}

Instrumen yang digunakan dalam penelitian ini adalah :

1. Jam yang digunakan untuk melakukan pengamatan aktivitas work dan idle terhadap pekerja yang diamati.

2. Pulpen yang digunakan sebagai alat tulis.

3. Lembar pengamatan dan alat tulis yang digunakan pada kegiatan pengamatan pekerja.

4. Kuisoner Standard Nordic Questionnaire (SNQ)

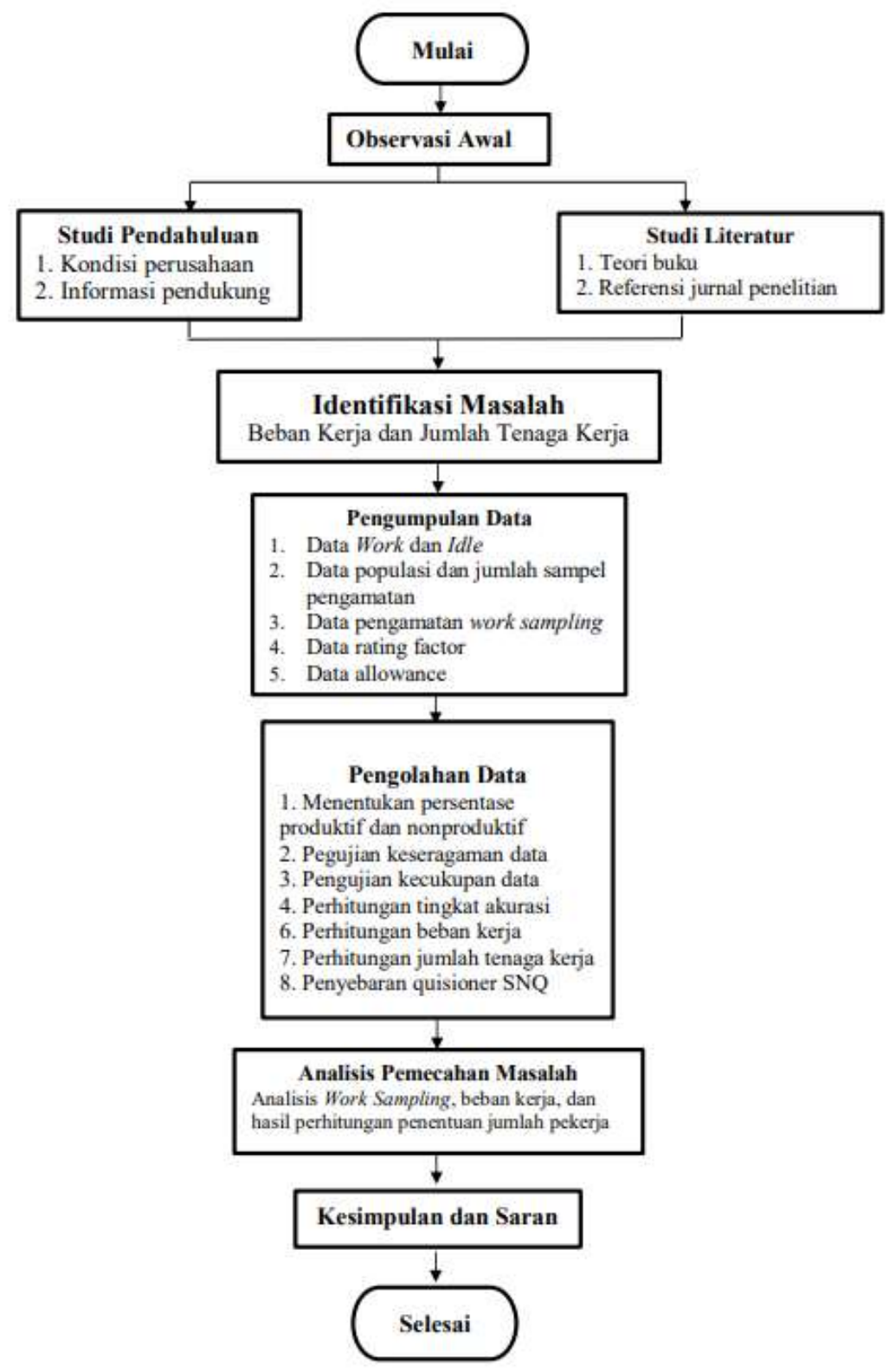

Gambar 1. Diagram Alir Penelitian 


\section{HASIL DAN PEMBAHASAN}

Penentuan Jumlah Tenaga Kerja dengan Metode Workload Analysis

Pengumpulan data dilakukan dengan melakukan pengamatan secara langsung menggunakan metode work sampling terhadap pekerja bagian pencetakan di UD. Budi Ayu. Pengamatan work sampling dilakukan selama 6 hari kerja. Pengamatan dimulai pada hari Senin, 23 Agustus 2021 sampai dengan hari Sabtu, 28 Agustus 2021. Pengamatan di mulai pada pukul 07.00 WITA sampai dengan pukul 13.00 WITA (istirahat pukul 12.00-12.30) dengan mengamati work dan idle pekerja dan menentukan Allowance serta rating factor setiap pekerja. Pengumpulan data juga dilakukan melalui informasi dari atasan dan wawancara langsung dengan pekerja mengenai jumlah pekerja dan uraian elemen kerja setiap pekerja selain dari observasi langsung.
Penelitian ini menggunakan tingkat ketelitian $8 \%$ dan tingkat keyakinan 95\%. Artinya bahwa selama pengamatan, dibolehkan rata-rata hasil pengukuran menyimpang sejauh maksimal $8 \%$ dari yang seharusnya dan kemungkinan berhasil mendapatkannya adalah $95 \%$

\section{Definisi Work dan Idle Pekerja}

Pada bagian produksi di UD. Budi Ayu dengan 6 orang pekerja yang memiliki tugas yang berbeda. Definisi dari kegiatan work di bagian produksi diketahui melalui job description, pengamatan langsung, dan melalui wawancara dengan pekerja dan atasannya. Elemen kegiatan idle setiap pekerja adalah segala sesuatu kegiatan yang dilakukan oleh operator diluar dari definisi worknya. Rincian aktivitas dan jumlah pekerja tiap stasiun adalah sebagai berikut.

Tabel 1. Aktivitas Pekerja tiap Bagian Produksi UD. Budi Ayu

\begin{tabular}{|c|c|c|c|}
\hline No & Bagian Kerja & Aktivitas & Jumlah Tenaga Kerja \\
\hline 1 & Pengaduk & $\begin{array}{l}\text { a. Mengecek mesin mixer } \\
\text { b. Menghidupkan mesin mixer } \\
\text { c. Menyiapkan bahan baku } \\
\text { d. Memasukkan bahan baku } \\
\text { ke mesin mixer } \\
\text { e. Mengeluarkan adonan dari } \\
\text { mixer } \\
\text { f. Mematikan mesin mixer } \\
\text { g. Membersihkan sisa adonan } \\
\text { didalam mesin mixer }\end{array}$ & 1 \\
\hline 2 & Pencetakan/press & $\begin{array}{l}\text { a. Mengecek mesin } \\
\text { b. Menghidupkan mesin } \\
\text { c. Memasukkan bahan } \\
\text { kecetakan } \\
\text { d. Mempress bahan menjadi } \\
\text { batako }\end{array}$ & 2 \\
\hline 3 & Penyusun & $\begin{array}{l}\text { a. Menurunkan papan kayu } \\
\text { b. Mengambil batako dari } \\
\text { mesin press } \\
\text { c. Menyusun batako di rak } \\
\text { d. Mengecek cacat pada hasil } \\
\text { batako yang dicetak } \\
\text { e. Menurunkan batako dari } \\
\text { rak } \\
\text { f. Menyusun batako } \\
\text { dilapangan } \\
\text { g. Mencat permukaan atas } \\
\text { batako sesuai orderan }\end{array}$ & 2 \\
\hline 4 & Batako Dinding & $\begin{array}{l}\text { a. Menyiapkan bahan baku } \\
\text { b. Mencampurkan bahan baku } \\
\text { secara manual } \\
\text { c. Mencetak bahan baku } \\
\text { secara manual } \\
\text { d. Menyusun batako }\end{array}$ & 1 \\
\hline
\end{tabular}

\section{Penentuan Waktu Pengamatan}

Waktu pengamatan ditetapkan setiap selang 5 menit, dengan teknik pengambilan sampel adalah systematic random sampling. Waktu-waktu pengamatan ditentukan selama 5,5 jam secara random yaitu melalui pukul 07.00
WITA sampai dengan pukul 13.00 WITA (istirahat 12.0012.30 WITA)

Untuk menentukan banyaknya bilangan random yang diperlukan selama total waktu kerja dapat dilihat dari perhitungan berikut ini: 


$$
\begin{aligned}
\text { Banyaknya Populasi Pengamatan } & =\frac{\text { Total Waktu Kerja x 60 Menit }}{\Delta \mathrm{t}} \\
& =\frac{5,5 \times 60 \text { Menit }}{5}=66
\end{aligned}
$$

Perhitungan diatas menunjukkan bahwa jumlah pengamatan per satu hari kerja $(5,5$ jam $)$ mempunyai 66 satuan waktu. Ini berarti jumlah pengamatan perhari tidak lebih dari 66 kali. Hasil penyusunan waktu pengamatan berdasarkan interval waktu dapat dilihat pada Tabel 2 .

Tabel 2. Waktu Pengamatan Work Sampling

\begin{tabular}{|c|c|c|c|c|c|c|c|}
\hline No & Waktu & No & Waktu & No & Waktu & No & Waktu \\
\hline $\mathbf{1}$ & $07: 00: 00$ & $\mathbf{1 8}$ & $08: 25: 00$ & $\mathbf{3 5}$ & $09: 50: 00$ & $\mathbf{5 2}$ & $11: 15: 00$ \\
\hline $\mathbf{2}$ & $07: 05: 00$ & $\mathbf{1 9}$ & $08: 30: 00$ & $\mathbf{3 6}$ & $09: 55: 00$ & $\mathbf{5 3}$ & $11: 20: 00$ \\
\hline $\mathbf{3}$ & $07: 10: 00$ & $\mathbf{2 0}$ & $08: 35: 00$ & $\mathbf{3 7}$ & $10: 00: 00$ & $\mathbf{5 4}$ & $11: 25: 00$ \\
\hline $\mathbf{4}$ & $07: 15: 00$ & $\mathbf{2 1}$ & $08: 40: 00$ & $\mathbf{3 8}$ & $10: 05: 00$ & $\mathbf{5 5}$ & $11: 30: 00$ \\
\hline $\mathbf{5}$ & $07: 20: 00$ & $\mathbf{2 2}$ & $08: 45: 00$ & $\mathbf{3 9}$ & $10: 10: 00$ & $\mathbf{5 6}$ & $11: 35: 00$ \\
\hline $\mathbf{6}$ & $07: 25: 00$ & $\mathbf{2 3}$ & $08: 50: 00$ & $\mathbf{4 0}$ & $10: 15: 00$ & $\mathbf{5 7}$ & $11: 40: 00$ \\
\hline $\mathbf{7}$ & $07: 30: 00$ & $\mathbf{2 4}$ & $08: 55: 00$ & $\mathbf{4 1}$ & $10: 20: 00$ & $\mathbf{5 8}$ & $11: 45: 00$ \\
\hline $\mathbf{8}$ & $07: 35: 00$ & $\mathbf{2 5}$ & $09: 00: 00$ & $\mathbf{4 2}$ & $10: 25: 00$ & $\mathbf{5 9}$ & $11: 50: 00$ \\
\hline $\mathbf{9}$ & $07: 40: 00$ & $\mathbf{2 6}$ & $09: 05: 00$ & $\mathbf{4 3}$ & $10: 30: 00$ & $\mathbf{6 0}$ & $11: 55: 00$ \\
\hline $\mathbf{1 0}$ & $07: 45: 00$ & $\mathbf{2 7}$ & $09: 10: 00$ & $\mathbf{4 4}$ & $10: 35: 00$ & $\mathbf{6 1}$ & $12: 30: 00$ \\
\hline $\mathbf{1 1}$ & $07: 50: 00$ & $\mathbf{2 8}$ & $09: 15: 00$ & $\mathbf{4 5}$ & $10: 40: 00$ & $\mathbf{6 2}$ & $12: 35: 00$ \\
\hline $\mathbf{1 2}$ & $07: 55: 00$ & $\mathbf{2 9}$ & $09: 20: 00$ & $\mathbf{4 6}$ & $10: 45: 00$ & $\mathbf{6 3}$ & $12: 40: 00$ \\
\hline $\mathbf{1 3}$ & $08: 00: 00$ & $\mathbf{3 0}$ & $09: 25: 00$ & $\mathbf{4 7}$ & $10: 50: 00$ & $\mathbf{6 4}$ & $12: 45: 00$ \\
\hline $\mathbf{1 4}$ & $08: 05: 00$ & $\mathbf{3 1}$ & $09: 30: 00$ & $\mathbf{4 8}$ & $10: 55: 00$ & $\mathbf{6 5}$ & $12: 50: 00$ \\
\hline $\mathbf{1 5}$ & $08: 10: 00$ & $\mathbf{3 2}$ & $09: 35: 00$ & $\mathbf{4 9}$ & $11: 00: 00$ & $\mathbf{6 6}$ & $12: 55: 00$ \\
\hline $\mathbf{1 6}$ & $08: 15: 00$ & $\mathbf{3 3}$ & $09: 40: 00$ & $\mathbf{5 0}$ & $11: 05: 00$ & & \\
\hline $\mathbf{1 7}$ & $08: 20: 00$ & $\mathbf{3 4}$ & $09: 45: 00$ & $\mathbf{5 1}$ & $11: 10: 00$ & & \\
\hline
\end{tabular}

\section{Penentuan Jumlah Sampel}

Jumlah sampel yang diperlukan dapat dihitung dengan menggunakan rumus persamaan 2.1

$n=\frac{66}{1+66(0,08)^{2}}=46$
Hasil dari perhitungan diatas menunjukkan bahwa pada penelitian ini diambil sampel 46 kali pengamatan dalam satu hari. Pengamatan dilakukan dengan metode randomisasi. Metode ini dibantu dengan Microsoft Excel dengan formula RAND dan RANK untuk menemukan kapan waktu pengamatan. Waktu pengamatan hasil metode randomisasi dengan Microsoft Excel dapat dilihat pada Tabel 3.

Tabel 3. Waktu Pengamatan Terpilih dalam Satu Hari Kerja

\begin{tabular}{|c|c|c|c|c|c|}
\hline No & $\begin{array}{c}\text { Bilangan } \\
\text { Random }\end{array}$ & Waktu & No & $\begin{array}{c}\text { Bilangan } \\
\text { Random }\end{array}$ & Waktu \\
\hline $\mathbf{1}$ & 1 & $07: 00: 00$ & $\mathbf{2 4}$ & 29 & $09: 20: 00$ \\
\hline $\mathbf{2}$ & 2 & $07: 10: 00$ & $\mathbf{2 5}$ & 30 & $09: 25: 00$ \\
\hline $\mathbf{3}$ & 4 & $07: 15: 00$ & $\mathbf{2 6}$ & 31 & $09: 30: 00$ \\
\hline $\mathbf{4}$ & 5 & $07: 20: 00$ & $\mathbf{2 7}$ & 32 & $09: 35: 00$ \\
\hline $\mathbf{5}$ & 6 & $07: 25: 00$ & $\mathbf{2 8}$ & 33 & $09: 40: 00$ \\
\hline $\mathbf{6}$ & 7 & $07: 30: 00$ & $\mathbf{2 9}$ & 34 & $09: 45: 00$ \\
\hline $\mathbf{7}$ & 8 & $07: 35: 00$ & $\mathbf{3 0}$ & 35 & $09: 50: 00$ \\
\hline $\mathbf{8}$ & 9 & $07: 40: 00$ & $\mathbf{3 1}$ & 37 & $10: 00: 00$ \\
\hline $\mathbf{9}$ & 10 & $07: 45: 00$ & $\mathbf{3 2}$ & 39 & $10: 10: 00$ \\
\hline $\mathbf{1 0}$ & 11 & $07: 50: 00$ & $\mathbf{3 2}$ & 41 & $10: 20: 00$ \\
\hline $\mathbf{1 1}$ & 12 & $07: 55: 00$ & $\mathbf{3 4}$ & 42 & $10: 25: 00$ \\
\hline $\mathbf{1 2}$ & 13 & $08: 00: 00$ & $\mathbf{3 5}$ & 43 & $10: 30: 00$ \\
\hline $\mathbf{1 3}$ & 16 & $08: 15: 00$ & $\mathbf{3 6}$ & 45 & $10: 40: 00$ \\
\hline $\mathbf{1 4}$ & 17 & $08: 20: 00$ & $\mathbf{3 7}$ & 47 & $10: 50: 00$ \\
\hline $\mathbf{1 5}$ & 18 & $08: 25: 00$ & $\mathbf{3 8}$ & 48 & $10: 55: 00$ \\
\hline $\mathbf{1 6}$ & 19 & $08: 30: 00$ & $\mathbf{3 9}$ & 49 & $11: 00: 00$ \\
\hline $\mathbf{1 7}$ & 21 & $08: 40: 00$ & $\mathbf{4 0}$ & 54 & $11: 25: 00$ \\
\hline $\mathbf{1 8}$ & 22 & $08: 45: 00$ & $\mathbf{4 1}$ & 57 & $11: 40: 00$ \\
\hline $\mathbf{1 9}$ & 23 & $08: 50: 00$ & $\mathbf{4 2}$ & 58 & $11: 45: 00$ \\
\hline $\mathbf{2 0}$ & 24 & $08: 55: 00$ & $\mathbf{4 3}$ & 60 & $11: 55: 00$ \\
\hline $\mathbf{2 1}$ & 26 & $09: 05: 00$ & $\mathbf{4 4}$ & 62 & $12: 35: 00$ \\
\hline $\mathbf{2 2}$ & 27 & $09: 10: 00$ & $\mathbf{4 5}$ & 63 & $12: 40: 00$ \\
\hline $\mathbf{2 3}$ & 28 & $09: 15: 00$ & $\mathbf{4 6}$ & 66 & $12: 55: 00$ \\
\hline & & & & & \\
\hline
\end{tabular}




\section{Kegiatan Work Sampling}

Pada waktu-waktu terpilih seperti yang tertera pada Tabel 3 dilakukan pengamatan aktivitas pekerja yang rekapitulasi hasilnya (work dan idle) selama 6 hari pengamatan dapat dilihat pada Tabel 4.

Tabel 4. Rekapitulasi Pengamatan Work Sampling

\begin{tabular}{|c|c|c|c|c|c|c|c|c|}
\hline \multirow{2}{*}{ No } & \multirow{2}{*}{$\begin{array}{l}\text { Bagian Kerja } \\
\text { (Pekerja ke -) }\end{array}$} & \multirow{2}{*}{ Aktivitas } & \multicolumn{6}{|c|}{ Pengamatan Hari Ke- } \\
\hline & & & 1 & 2 & 3 & 4 & 5 & 6 \\
\hline \multirow{3}{*}{1} & \multirow{3}{*}{$\begin{array}{l}\text { Pengaduk } \\
\text { (Pekerja 1) }\end{array}$} & Work & 37 & 36 & 33 & 39 & 34 & 42 \\
\hline & & Idle & 9 & 10 & 13 & 7 & 12 & 4 \\
\hline & & Total & 46 & 46 & 46 & 46 & 46 & 46 \\
\hline \multirow{3}{*}{2} & \multirow{3}{*}{$\begin{array}{c}\text { Pencetakan / Press } \\
\text { (Pekerja 2) }\end{array}$} & Work & 37 & 38 & 35 & 43 & 37 & 41 \\
\hline & & Idle & 9 & 8 & 11 & 3 & 9 & 5 \\
\hline & & Total & 46 & 46 & 46 & 46 & 46 & 46 \\
\hline \multirow{3}{*}{3} & \multirow{3}{*}{$\begin{array}{c}\text { Pencetakan / Press } \\
\text { (Pekerja 3) }\end{array}$} & Work & 38 & 39 & 38 & 44 & 39 & 44 \\
\hline & & Idle & 8 & 7 & 8 & 2 & 7 & 2 \\
\hline & & Total & 46 & 46 & 46 & 46 & 46 & 46 \\
\hline \multirow{3}{*}{4} & \multirow{3}{*}{$\begin{array}{l}\text { Penyusun } \\
\text { (Pekerja 4) }\end{array}$} & Work & 40 & 42 & 37 & 44 & 38 & 43 \\
\hline & & Idle & 6 & 4 & 9 & 2 & 8 & 3 \\
\hline & & Total & 46 & 46 & 46 & 46 & 46 & 46 \\
\hline \multirow{3}{*}{5} & \multirow{3}{*}{$\begin{array}{l}\text { Penyusun } \\
\text { (Pekerja 5) }\end{array}$} & Work & 35 & 34 & 35 & 33 & 35 & 33 \\
\hline & & Idle & 11 & 12 & 11 & 13 & 11 & 13 \\
\hline & & Total & 46 & 46 & 46 & 46 & 46 & 46 \\
\hline \multirow{3}{*}{6} & \multirow{3}{*}{$\begin{array}{l}\text { Batako Dinding } \\
\text { (Pekerja 6) }\end{array}$} & Work & 45 & 45 & 44 & 45 & 45 & 44 \\
\hline & & Idle & 1 & 1 & 2 & 1 & 1 & 2 \\
\hline & & Total & 46 & 46 & 46 & 46 & 46 & 46 \\
\hline
\end{tabular}

Tabel 5. Rating Westinghouse Factor Masing-masing Pekerja

\begin{tabular}{|c|cccc|c|c|}
\hline Pekerja Ke- & \multicolumn{5}{|c|}{ Nilai Westinghouse factor } & \multirow{2}{*}{ TOTAL } \\
\hline & Skill & Effort & Kondisi Kerja & Konsistensi & \\
\hline $\mathbf{1}$ & $+0,06$ & $+0,02$ & $+0,00$ & $+0,00$ & 0,08 \\
\hline $\mathbf{2}$ & $+0,06$ & $+0,02$ & $+0,00$ & $+0,01$ & 0,09 \\
\hline $\mathbf{3}$ & $+0,06$ & $+0,02$ & $+0,00$ & $+0,01$ & 0,09 \\
\hline $\mathbf{4}$ & $+0,06$ & $+0,02$ & $+0,00$ & $+0,01$ & 0,08 \\
\hline $\mathbf{5}$ & $+0,03$ & $-0,04$ & $+0,00$ & $+0,00$ & $-0,01$ \\
\hline
\end{tabular}

Tabel 6. Rekapitulasi Rating Factor Masing-masing Pekerja

\begin{tabular}{|c|c|c|}
\hline $\begin{array}{c}\text { Pekerja } \\
\text { Ke- }\end{array}$ & $\begin{array}{c}\text { Westinghouse } \\
\text { Factor }\end{array}$ & $\begin{array}{c}\text { Rating } \\
\text { Factor }\end{array}$ \\
\hline $\mathbf{1}$ & 0,08 & 1,08 \\
\hline $\mathbf{2}$ & 0,09 & 1,09 \\
\hline $\mathbf{3}$ & 0,09 & 1,09 \\
\hline $\mathbf{4}$ & 0,08 & 1,08 \\
\hline $\mathbf{5}$ & $-0,01$ & 0,99 \\
\hline $\mathbf{6}$ & 0,08 & 1,08 \\
\hline
\end{tabular}

Allowance

1. Bagian Pengaduk

Tabel 7. Nilai Allowance Pekerja Bagian Pengaduk

\begin{tabular}{|c|c|c|c|}
\hline No & Allowance & Keadaan & $\%$ \\
\hline $\mathbf{1}$ & Tenaga yang dikeluarkan & Ringan & \\
\hline
\end{tabular}




\begin{tabular}{|l|l|l|r|}
\hline $\mathbf{2}$ & Sikap kerja & Berdiri diatas dua kaki & 1,0 \\
\hline $\mathbf{3}$ & Gerakan kerja & Normal & 0,0 \\
\hline $\mathbf{4}$ & Kelelahan mata & Pandangan yang terputus-putus & 0,5 \\
\hline $\mathbf{5}$ & $\begin{array}{l}\text { Keadaan temperatur tempat } \\
\text { kerja }\end{array}$ & Normal & 2,0 \\
\hline $\mathbf{6}$ & Keadaan Atmosfer & Kurang Baik & 5,0 \\
\hline $\mathbf{7}$ & Keadaan Lingkungan & Siklus berulang-ulang & 1,0 \\
\hline $\mathbf{8}$ & Pria & & 1,0 \\
\hline & Total & & $\mathbf{1 8}$ \\
\hline
\end{tabular}

2. Bagian Pencetakan

Tabel 8. Nilai Allowance Pekerja Bagian Pencetakan

\begin{tabular}{|c|l|l|c|}
\hline No & \multicolumn{1}{|c|}{ Allowance } & \multicolumn{1}{|c|}{ Keadaan } & \% \\
\hline $\mathbf{1}$ & Tenaga yang dikeluarkan & Ringan & 6,5 \\
\hline $\mathbf{2}$ & Sikap kerja & Berdiri diatas dua kaki & 1,0 \\
\hline $\mathbf{3}$ & Gerakan kerja & Normal & 0,0 \\
\hline $\mathbf{4}$ & Kelelahan mata & Pandangan yang terputus-putus & 1,0 \\
\hline $\mathbf{5}$ & Keadaan temperatur tempat kerja & Normal & 2,0 \\
\hline $\mathbf{6}$ & Keadaan Atmosfer & Kurang Baik & 5,0 \\
\hline $\mathbf{7}$ & Keadaan Lingkungan & Siklus berulang-ulang & 1,0 \\
\hline $\mathbf{8}$ & Pria & & 1,0 \\
\hline & Total & & $\mathbf{1 7 , 5}$ \\
\hline
\end{tabular}

3. Bagian Penyusunan

Tabel 9. Nilai Allowance Pekerja Bagian Penyusunan

\begin{tabular}{|c|l|l|c|}
\hline No & \multicolumn{1}{|c|}{ Allowance } & \multicolumn{1}{|c|}{ Keadaan } & \% \\
\hline $\mathbf{1}$ & Tenaga yang dikeluarkan & Ringan & 5 \\
\hline $\mathbf{2}$ & Sikap kerja & Berdiri diatas dua kaki & 1,5 \\
\hline $\mathbf{3}$ & Gerakan kerja & Normal & 0,0 \\
\hline $\mathbf{4}$ & Kelelahan mata & Pandangan yang terputus-putus & 7,5 \\
\hline $\mathbf{5}$ & Keadaan temperatur tempat kerja & Normal & 2,0 \\
\hline $\mathbf{6}$ & Keadaan Atmosfer & Kurang Baik & 5,0 \\
\hline $\mathbf{7}$ & Keadaan Lingkungan & Siklus berulang-ulang & 1,0 \\
\hline $\mathbf{8}$ & Pria & & 1,0 \\
\hline & Total & & $\mathbf{2 3}$ \\
\hline
\end{tabular}

4. Bagian Batako Dinding

Tabel 10. Nilai Allowance Pekerja Batako Dinding

\begin{tabular}{|c|l|l|c|}
\hline No & \multicolumn{1}{|c|}{ Allowance } & \multicolumn{1}{|c|}{ Keadaan } & \% \\
\hline $\mathbf{1}$ & Tenaga yang dikeluarkan & Ringan & 6,5 \\
\hline $\mathbf{2}$ & Sikap kerja & Berdiri diatas dua kaki & 1,0 \\
\hline $\mathbf{3}$ & Gerakan kerja & Normal & 0,0 \\
\hline $\mathbf{4}$ & Kelelahan mata & Pandangan yang terputus-putus & 1,0 \\
\hline $\mathbf{5}$ & Keadaan temperatur tempat kerja & Normal & 2,0 \\
\hline $\mathbf{6}$ & Keadaan Atmosfer & Kurang Baik & 5,0 \\
\hline $\mathbf{7}$ & Keadaan Lingkungan & Siklus berulang-ulang & 1,0 \\
\hline $\mathbf{8}$ & Pria & & 1,0 \\
\hline & Total & & $\mathbf{1 7 , 5}$ \\
\hline
\end{tabular}

Perhitungan Persentase Waktu Produktif

Perhitungan persentase produktif pekerja 1 pada hari 1 adalah:

$\%$ Produktif $=\frac{37}{46} \times 100 \%=0,8043 \%$
Data rekapitulasi waktu produktif masing-masing pekerja pada setiap bagian kerja dapat dilihat pada Tabel 11 
Tabel 11. Rekapitulasi Waktu Produktif Masing-masing Pekerja

\begin{tabular}{|c|c|c|c|c|c|c|c|}
\hline Pekerja & Aktivitas & Hari 1 & Hari 2 & Hari 3 & Hari 4 & Hari 5 & Hari 6 \\
\hline 1 & $\begin{array}{c}\text { Work } \\
\text { Idle } \\
\text { Total } \\
\text { \% Produktif } \\
\text { \% P Rata-rata }\end{array}$ & $\begin{array}{c}37 \\
9 \\
46 \\
0,8043\end{array}$ & $\begin{array}{c}36 \\
10 \\
46 \\
0,7826\end{array}$ & $\begin{array}{c}33 \\
13 \\
46 \\
0,7173 \\
0,8006\end{array}$ & $\begin{array}{c}39 \\
7 \\
46 \\
0,8478\end{array}$ & $\begin{array}{c}34 \\
12 \\
46 \\
0,7391\end{array}$ & $\begin{array}{c}42 \\
4 \\
46 \\
0,9130\end{array}$ \\
\hline 2 & $\begin{array}{c}\text { Work } \\
\text { Idle } \\
\text { Total } \\
\text { \% Produktif } \\
\text { \% P Rata-rata }\end{array}$ & $\begin{array}{c}37 \\
9 \\
46 \\
0,8043\end{array}$ & $\begin{array}{c}38 \\
8 \\
46 \\
0,8260\end{array}$ & $\begin{array}{c}35 \\
11 \\
46 \\
0,7608 \\
0,8369\end{array}$ & $\begin{array}{c}43 \\
3 \\
46 \\
0,9347\end{array}$ & $\begin{array}{c}37 \\
9 \\
46 \\
0,8043\end{array}$ & $\begin{array}{c}41 \\
5 \\
46 \\
0,8913\end{array}$ \\
\hline 3 & $\begin{array}{c}\text { Work } \\
\text { Idle } \\
\text { Total } \\
\text { \% Produktif } \\
\text { \% P Rata-rata }\end{array}$ & $\begin{array}{c}38 \\
8 \\
46 \\
0,8260\end{array}$ & $\begin{array}{c}39 \\
7 \\
46 \\
0,8478\end{array}$ & $\begin{array}{c}48 \\
8 \\
46 \\
0,8260 \\
0,8767\end{array}$ & $\begin{array}{c}44 \\
2 \\
46 \\
0,9565\end{array}$ & $\begin{array}{c}39 \\
7 \\
46 \\
0,8478\end{array}$ & $\begin{array}{c}44 \\
2 \\
57 \\
0,9565\end{array}$ \\
\hline 4 & $\begin{array}{c}\text { Work } \\
\text { Idle } \\
\text { Total } \\
\text { \% Produktif } \\
\text { \% P Rata-rata }\end{array}$ & $\begin{array}{c}40 \\
6 \\
46 \\
0,8695\end{array}$ & $\begin{array}{c}42 \\
4 \\
46 \\
0,9130\end{array}$ & $\begin{array}{c}37 \\
9 \\
46 \\
0,8043 \\
0,8840\end{array}$ & $\begin{array}{c}44 \\
2 \\
46 \\
0,9565\end{array}$ & $\begin{array}{c}38 \\
8 \\
46 \\
0,8260\end{array}$ & $\begin{array}{c}43 \\
3 \\
46 \\
0,9347\end{array}$ \\
\hline 5 & $\begin{array}{c}\text { Work } \\
\text { Idle } \\
\text { Total } \\
\text { \% Produktif } \\
\text { \% P Rata-rata }\end{array}$ & $\begin{array}{c}35 \\
11 \\
46 \\
0,7608\end{array}$ & $\begin{array}{c}34 \\
12 \\
46 \\
0,7391\end{array}$ & $\begin{array}{c}35 \\
11 \\
46 \\
0,7608 \\
0,7426\end{array}$ & $\begin{array}{c}33 \\
13 \\
46 \\
0,7173\end{array}$ & $\begin{array}{c}35 \\
11 \\
46 \\
0,7608\end{array}$ & $\begin{array}{c}33 \\
13 \\
46 \\
0,7173\end{array}$ \\
\hline 6 & $\begin{array}{c}\text { Work } \\
\text { Idle } \\
\text { Total } \\
\text { \% Produktif } \\
\text { \% P Rata-rata }\end{array}$ & $\begin{array}{c}45 \\
1 \\
46 \\
0,9782\end{array}$ & $\begin{array}{c}45 \\
1 \\
46 \\
0,9782\end{array}$ & $\begin{array}{c}44 \\
2 \\
46 \\
0,9565 \\
0,9709\end{array}$ & $\begin{array}{c}45 \\
1 \\
46 \\
0,9782\end{array}$ & $\begin{array}{c}45 \\
1 \\
46 \\
0,9782\end{array}$ & $\begin{array}{c}44 \\
2 \\
46 \\
0,9565\end{array}$ \\
\hline
\end{tabular}

Hasil pengolahan data menunjukkan bahwa persentase waktu produktif paling besar di miliki oleh bagian batako dinding(pekerja 6) sebesar 97,09\% dan yang paling rendah dimiliki oleh bagian peyusunan(pekerja 5) sebesar $0,7426 \%$.
Jika dibandingkan waktu produktif actual dengan waktu produktif seharusnya, maka dapat diketahui bahwa pekerja masih memiliki waktu non produktif (idle) dengan persentase berbeda-beda. Rekapitulasi Waktu Produktif, Idle dan Allowance dapat dilihat pada tabel 12 .

Tabel 12. Rekapitulasi Waktu Produktif, Idle, Allowance

\begin{tabular}{|l|l|l|l|l|l|}
\hline \multicolumn{1}{|c|}{ Bagian } & $\begin{array}{c}\text { Pekerja } \\
\text { Ke- }\end{array}$ & $\begin{array}{c}\text { \%Waktu } \\
\text { Produktif }\end{array}$ & Idle & Allowance & $\begin{array}{c}\text { Selisih Idle } \\
\text { dengan } \\
\text { Allowance }\end{array}$ \\
\hline Pengadukan & 1 & 80,06 & 19,94 & 18 & 1,94 \\
\hline Pencetakan & 2 & 83,69 & 16,31 & 17,5 & $-1,19$ \\
& 3 & 87,67 & 12,33 & 17,5 & $-5,17$ \\
\hline Penyusunan & 4 & 88,40 & 11,60 & 23 & $-11,4$ \\
\hline Batako Dinding & 5 & 74,26 & 25,74 & 23 & 2,74 \\
\hline
\end{tabular}

Selisih Idle dan Allowance yang bernilai positif menunjukkan bahwa pekerja memiliki waktu yang tidak produktif yaitu memiliki waktu luang yang lebih besar dari Allowance yang diberikan. Pada Tabel 12 menunjukkan bahwa hanya bagian pengadukan (pekerja 1) dan bagian penyusunan (pekerja 5) yang memiliki waktu luang yang lebih besar dibandingkan pekerja yang lain.
Uji Keseragaman Data

Perhitungan BKA dan BKB pekerja 1 adalah:

$$
\begin{aligned}
& \overline{\mathrm{p}}=\frac{0,8043+0,7826+0,7173+0,8478+0,7391+0,9310}{6}=0,8006 \\
& \mathrm{BKA}=0,8006+1,96 \sqrt{\frac{0,8006(1-0,8006)}{46}}=0,9160
\end{aligned}
$$


$\mathrm{BKB}=0,8006-1,96 \sqrt{\frac{0,8006(1-0,8006)}{46}}=0,6852$

Tabel 13. Hasil Uji Keseragaman Data

\begin{tabular}{|c|c|c|c|c|}
\hline No & Pekerja & BKA & BKB & Keterangan \\
\hline $\mathbf{1}$ & Pekerja 1 & 0,9160 & 0,6852 & Seragam \\
\hline $\mathbf{2}$ & Pekerja 2 & 0,9420 & 0,7318 & Seragam \\
\hline $\mathbf{3}$ & Pekerja 3 & 0,9718 & 0,7816 & Seragam \\
\hline $\mathbf{4}$ & Pekerja 4 & 0,9765 & 0,7915 & Seragam \\
\hline $\mathbf{5}$ & Pekerja 5 & 0,8689 & 0,6163 & Seragam \\
\hline $\mathbf{6}$ & Pekerja 6 & 1,0194 & 0,9224 & Seragam \\
\hline
\end{tabular}

\section{Uji Kecukupan Data}

Penelitian dilakukan dengan tingkat ketelitian 8\% sehingga jumlah pengamatan yang perlu dilakukan adalah sebagai berikut :
Jumlah pengamatan $(\mathrm{N})$ yang dilakukan adalah 369 dan hasil perhitungan (N') adalah 150 , dapat dilihat bahwa $\mathrm{N}^{\prime}<\mathrm{N}$, maka data dikatakan sudah cukup. Rekapitulasi pengujian kecukupan data dapat dilihat pada Tabel 14.

$\mathrm{N}^{\prime}=\frac{1,96^{2}(1-0,8006)}{\left(0,08^{2}\right)(0,8006)}=149,5 \approx 150$

Tabel 14. Rekapitulasi Uji Kecukupan Data

\begin{tabular}{|c|c|c|c|c|}
\hline Pekerja Ke- & N & \%P & N & Keterangan \\
\hline $\mathbf{1}$ & 396 & 0,8006 & 150 & Cukup \\
\hline $\mathbf{2}$ & 396 & 0,8369 & 117 & Cukup \\
\hline $\mathbf{3}$ & 396 & 0,8767 & 84 & Cukup \\
\hline $\mathbf{4}$ & 396 & 0,8840 & 79 & Cukup \\
\hline $\mathbf{5}$ & 396 & 0,7426 & 208 & Cukup \\
\hline $\mathbf{6}$ & 396 & 0,9709 & 18 & Cukup \\
\hline
\end{tabular}

\section{Perhitungan Tingkat Akurasi}

Perhitungan rata-rata persentase waktu produktif seluruh pekerja pada bagian produksi adalah :

$\overline{\mathrm{p}}=\frac{0,8006+0,8369+0,8767+0,8840+0,7426+0,9709}{6}=0,85195$

Perhitungan tingkat akurasi dapat dilihat sebagai berikut :

$S=\frac{1,96}{0,85195} \sqrt{\frac{0,85195(1-0,85195)}{369}}=0,0425$

Nilai $s= \pm 4,25 \%$ atau lebih kecil dari $8 \%$ (tingkat ketelitian yang ditetapkan), maka penelitian yang dilakukan sudah lebih teliti dari yang dipersyaratkan di awal penelitian.

\section{Perhitungan Beban Kerja}

Setelah melakukan uji kecukupan data langkah selanjutnya yaitu melakukan perhitungan beban kerja fisik dari para pekerja. Perhitungan beban kerja fisik pekerja dipengaruhi oleh rating factor dan Allowance. Berikut perhitungan beban kerja fisik para pekerja berdasarkan persamaan rumus

Perhitungan beban kerja pada pekerja 1 adalah:

Beban Kerja: $0.8006 \times(1,08) \times(1+0,18)=1,0203$

Perhitungan beban kerja pada pekerja 2 adalah:

Beban Kerja: $0,8369 \times(1,09) \times(1+0,175)=1,0719$

Perhitungan beban kerja pada pekerja 3 adalah:

Beban Kerja: $0,8767 \times(1,09) \times(1+0,175)=1,1223$

Perhitungan beban kerja pada pekerja 4 adalah:

Beban Kerja: $0,8840 \times(1.08) \times(1+0,23)=1,1743$

Perhitungan beban kerja pada pekerja 5 adalah:

Beban Kerja: $0,7425 \times(0,99) \times(1+0,23)=0,9041$ 
Perhitungan beban kerja pada pekerja 6 adalah:

Beban Kerja: 0,9709 x $(1,08) \times(1+0,175)=1,2320$
Rekapitulasi beban kerja untuk masing-masing bagian kerja dapat dilihat pada Tabel 15.

Tabel 15. Rekapitulasi Persentase Beban Kerja

\begin{tabular}{|c|c|c|}
\hline $\begin{array}{c}\text { Pekerja } \\
\text { Ke- }\end{array}$ & \%Produktif & $\begin{array}{c}\text { Persentase Beban } \\
\text { Kerja \% }\end{array}$ \\
\hline $\mathbf{1}$ & 0,8006 & $102,03 \%$ \\
\hline $\mathbf{2}$ & 0,8369 & $107,19 \%$ \\
\hline $\mathbf{3}$ & 0,8767 & $112,23 \%$ \\
\hline $\mathbf{4}$ & 0,8840 & $117,43 \%$ \\
\hline $\mathbf{5}$ & 0,7426 & $90,41 \%$ \\
\hline $\mathbf{6}$ & 0,9709 & $123,2 \%$ \\
\hline
\end{tabular}

Berdasarkan perhitungan yang dilakukan beban kerja pada pekerja bagian pengadukan sebesar $102,03 \%$, beban kerja pada bagian pencetakan sebesar $107,19 \%+112,23 \%=$ $219,42 \%$, beban kerja pada bagian penyusunan sebesar $117,43 \%+90,41 \%=207,84 \%$ dan beban kerja pada bagian batako dinding sebesar $123,2 \%$. Rata-rata beban kerja yaitu $102,03 \%$ pada bagian pengadukan, $109,71 \%$ pada bagian pencetakan, $103,92 \%$ pada bagian penyusunan dan $123,2 \%$ pada bagian batako dinding.

Rata-rata beban kerja disetiap stasiun kerja melebihi beban kerja normal (>100\%). Solusi yang dapat dilakukan adalah dengan menambah jumlah pekerja.

\section{Perhitungan Jumlah Pekerja dengan Workload Analysis}

Perhitungan jumlah pekerja yang dibutuhkan dilakukan dengan menjumlahkan nilai beban kerja seluruh pekerja yang berada di tiap bagian, sehingga diperoleh beban kerja per bagian. Penambahan tenaga kerja dilakukan pada stasiun batako dinding karena beban kerja yang diterima oleh pekerja pada bagian batako dinding paling besar diantara para pekerja.

Tabel 16. Rekapitulasi Beban Kerja Aktual dan Usulan

\begin{tabular}{|l|l|c|c|c|}
\hline No & \multicolumn{1}{|c|}{ Bagian } & $\begin{array}{c}\text { Beban Kerja } \\
\text { (Aktual) }\end{array}$ & $\begin{array}{c}\text { Tenaga Kerja } \\
\text { (Usulan) }\end{array}$ & $\begin{array}{c}\text { Beban Kerja } \\
\text { (Usulan) }\end{array}$ \\
\hline $\mathbf{1}$ & Pengadukan & $102,03 \%$ & 0 & $102,03 \%$ \\
\hline $\mathbf{2}$ & Cetakan & $107,19 \%$ & 0 & $107,19 \%$ \\
& & $112,23 \%$ & & $112,23 \%$ \\
\hline $\mathbf{3}$ & Penyusunan & $117,43 \%$ & 0 & $117,43 \%$ \\
& & $90,41 \%$ & & $90,41 \%$ \\
\hline $\mathbf{4}$ & Batako Dinding & $123,2 \%$ & 1 & $61,6 \%$ \\
& & & & $61,6 \%$ \\
\hline
\end{tabular}

Bila dilakukan penambahan pekerja 1 orang pada bagian batako dinding maka beban kerja yang dialami kedua pekerja sangat ringat yaitu sebesar $61,6 \%$ atau apabila pekerja 1 pada bagian batako dinding bekerja dengan normal yaitu $95 \%$ maka beban kerja yang diterima oleh pekerja 2 hanya sebesar $28,2 \%$. Maka dianggap bahwa pekerja awal pada bagian batako dinding tetap melakukan pekerjaannya secara normal yaitu $95 \%$.

Dengan jumlah pekerja 2 orang pekerja pada stasiun batako dinding maka pekerjaan pada bagian batako dinding akan lebih ringan daripada stasiun lainnya, menyebabkan banyak terjadi idle pada bagian dinding batako, maka pekerja tambahan tersebut ditugaskan untuk membantu pekerjaan pada stasiun lainnya setelah selesai melakukan pekerjaannya.

Pekerja pada bagian pencetakan perlu melakukan kegiatan menyekop adonan bata yang keluar dari mesin mixer. Karena hal ini terus terjadi saat adonan bata yang keluar dari mesin mixer menumpuk di lantai yang dapat menghambat proses pengadukan selanjutnya maka pekerja tambahan tersebut ditugaskan untuk menyekop adonan sehingga pekerja pada bagian pencetakan dapat fokus melakukan pekerjaannya serta dapat mengurangi beban kerja yang dialami mereka. Dan pada bagian pengadukan bisa membantu menyiapkan bahan yang letak nya agak jauh dari mesin mixer untuk mempercepat proses produksi. Dengan adanya pekerja tambahan yang membantu pekerjaan pada stasiun lainnya, beban kerja para pekerja pada stasiun lainnya dapat berkurang dan waktu mengganggur dari pekerja tambahan tersebut dapat berkurang.

\section{Mengetahui keluhan otot yang dirasakan pekerja}

Data ini didapatkan melalui penyebaran kuisoner SNQ. Data ini ditujukan untuk mengetahui bagian tubuh operator yang mengalami keluhan sewaktu melakukan aktivitasnya. Data hasil penyebaran Standard Nordic Questionnaire diberi penilaian atau pembobotan untuk masing-masing kategori sebagai berikut:

Tidak sakit: bobot 0

Agak sakit: bobot 1 
Sakit: bobot 2

Sangat sakit: bobot 3

Kuisoner SNQ diberikan kepada 6 orang pekerja bagian produksi dan terdiri dari pertanyaan ke-0 hingga ke-27.

Setelah dilakukan rekapitulasi skor bobot SNQ pada pengumpulan data dimana diperoleh total skor bobot SNQ sebesar 63. Kemudian data skor rekapitulasi tersebut dirubah kedalam persentase. Untuk mendapatkan persentase tersebut dapat dicari dengan rumus:

$\%$ Keluhan $=\frac{\text { Skor risiko bagian tubuh operator }}{J u m \quad \text { skor risiko bagian tubuh operator }} \times 100 \%$

Tabel 4. 4 Tabel Rekapitulasi Kuisoner SNQ

\begin{tabular}{|c|c|c|}
\hline Pertanyaan & $\begin{array}{c}\text { Total } \\
\text { Skor Bobot }\end{array}$ & Persentase \\
\hline $\mathbf{0}$ & 2 & $3,17 \%$ \\
\hline 1 & 2 & $3,17 \%$ \\
\hline 2 & 3 & $4,76 \%$ \\
\hline 3 & 2 & $3,17 \%$ \\
\hline 4 & 3 & $4,76 \%$ \\
\hline 5 & 1 & $1,59 \%$ \\
\hline 6 & 3 & $4,76 \%$ \\
\hline 7 & 8 & $12,70 \%$ \\
\hline 8 & 0 & $0,00 \%$ \\
\hline 9 & 0 & $0,00 \%$ \\
\hline 10 & 2 & $3,17 \%$ \\
\hline 11 & 2 & $3,17 \%$ \\
\hline 12 & 2 & $3,17 \%$ \\
\hline 13 & 2 & $3,17 \%$ \\
\hline 14 & 2 & $3,17 \%$ \\
\hline 15 & 3 & $4,76 \%$ \\
\hline 16 & 2 & $3,17 \%$ \\
\hline 17 & 2 & $3,17 \%$ \\
\hline 18 & 1 & $1,59 \%$ \\
\hline 19 & 1 & $1,59 \%$ \\
\hline 20 & 2 & $3,17 \%$ \\
\hline 21 & 3 & $4,76 \%$ \\
\hline 22 & 4 & $6,35 \%$ \\
\hline 23 & 4 & $6,35 \%$ \\
\hline 24 & 2 & $3,17 \%$ \\
\hline 25 & 2 & $3,17 \%$ \\
\hline 26 & 1 & $1,59 \%$ \\
\hline 27 & 2 & $3,17 \%$ \\
\hline
\end{tabular}

Berdasarkan hasil pengolahan data diperoleh bahwa ratarata pekerja mengalami keluhan terbesar di tubuh bagian pinggang sebesar $12,70 \%$. Dengan mengetahui presentasi keluhan yang dialami pekerja, maka dapat diberikan sosialisasi kepada para pekerja untuk memperbaiki postur kerja bila perlu dilakukan pengadaan alat untuk membantu operator dalam bekerja.

\section{KESIMPULAN DAN SARAN}

Kesimpulan yang diperoleh dari penelitian tentang analisis beban kerja dan jumlah tenaga kerja dan jumlah pekerja di UD. Budi Ayu adalah sebagai berikut:

1. Berdasarkan hasil perhitungan jumlah tenaga kerja dengan menggunakan metode workload analysis didapatkan penambahan karyawan 1 orang pada bagian batako dinding dikarenakan memiliki persentase beban kerja terbesar dibandingkan beban kerja bagian lain yaitu sebesar $123,2 \%$

2. Keluhan otot terbesar yang dialami pekerja selama bekerja yaitu pada tubuh bagian pinggang dengan persentase sebesar $12,70 \%$.

\section{DAFTAR PUSTAKA}

[1] Anggarak, Radhy. 2012. Pengukuran Produktivitas Berdasarkan Beban Kerja. Bogor

[2] Barnes, Ralph M. 1980. Motion and Time Study Design and Measurement of Work.

[3] Ginting, Rosnani dkk.2017. Penggunaan Kuisoner SNQ Untuk Analisis Keluhan Rasa Sakit Yang Dialami Pekerja Pada UKM Kerupuk Di Kota Medan. Universitas Sumatera Utara (USU) 
[4] Ginting, Rosnani. 2009. Perancangan Produk. Jogyakarta : Graha Ilmu

[5] Hoonaker, P., et al., 2011, Measuring workload of ICU nurses with questionnaire survey: the NASA Task load Index (TLX), USA: IIE Transactions on Healthcare System Engineering.

[6] Kourinka dkk.1987. Standardised Nordic Questionnaores: Applied Ergonomics

[7] Kurniawan Fajar Dwi, Nafisah Laila. 2020. Analisis Beban Kerja dan Penentuan Jumlah Tenaga Kerja pada Stasiun Penulangan Plant 1 dengan Metode Workload Analysis pada PT Wijaya Karya Beton. Universitas Pembangunan Nasional Veteran. Yogyakarta

[8] Moekijat. 1985. Manajemen personalia dan sumber daya manusia. Bandung : Mandar Maju

[9] Nasution, Harmein. 2008. Proses Pengelolaan Sumber Daya Manusia. Medan: USU Press.

[10] Niebel, Benjamin. 2007. Method Standards and Work Design. New York : MC Graw Hill.

[11] Putri,Raissa dkk. 2014. Analisis Beban Kerja Dengan Metode Workload Analysis Sebagai Pertimbangan
Pemberian Insentif Pekerja. Malang. Universitas Brawijaya.

[12] Riduwan, Arif. 2014. Analisis Beban Kerja pada Bagian Produksi dengan Pendekatan Metode WorkLoad Analysis. Universitas Pembangunan Nasional Veteran Jawa Timur

[13] Sari Endah Meila, Darmawan M Muchtar. 2020. Pengukuran Waktu Baku dan Analisis Beban Kerja Pada Proses Filling dan Packing Produk Lulur Mandi di PT. Gloria Origita Cosmetics. Universitas Pancasila.Jakarta

[14] Seventh Edition. New York: John Wiley \& Sons. Edison,Amron.2010. Pengembangan Sumber Daya Manusia:Human Resource Development. Bandung : Alfabeta

[15] Sinulingga, Sukaria. 2009. Metode Penelitian. Yogyakarta: Graha Ilmu

[16] Sutalaksana, I.Z., dkk. 1979. Teknik Tata Cara Kerja. Bandung

[17] Wignjosoebroto, Sritomo. 2006. Ergonomi Studi Gerak dan Waktu. Surabaya : Guna Widya 